\title{
СВОЙСТВА И ПРИМЕНЕНИЕ СТЕКЛОНАПОЛНЕННЫХ ПОЛИФЕНИЛЕНСУЛЬФИДОВ
}

\author{
А. В. Саморядов, В. Б. Иванов, Е.В. Калугина
}

\begin{abstract}
АЛЕКСАНДР ВЛАДИМИРОВИЧ САМОРЯДОВ - д.т.н, главный научный сотрудник ФГБУН межведомственного иентра аналитических исследований в области физики, химии и биологии при Президиуме РАН.

ВИКТОР БОРИСОВИЧ ИВАНОВ - д.х.н, профессор, заведующий лабораторией фотохимии полимеров ФГБУН федерального исследовательского ичентра химической физики имени Н.Н. Семенова РАН.
\end{abstract}

ЕЛЕНА ВЛАДИМИРОВНА КАЛУГИНА - д.х.н., профессор, начальник управления исследования материалов, заместитель директора НИИ «ПОЛИПЛАСТИК».

117997, Россия, г. Москва, ул. Профсоюзная, д. 65, стр. 6, ФГБУН Межведомственный центр аналитических исследований в области физики, химии и биологии при Президиуе РАН.

119991, Россия, г. Москва, ул. Косыгина, д. 4, ФГБУН Федеральный исследовательский центр химической физики имени Н.Н. Семенова РАН.

119530, Россия, г. Москва, ул. Генерала Дорохова, д. 14. Общество с ограниченной ответственностью «Группа ПОЛИПЛАСТИК».

Приведены термические, физико-механические, электро-, теплофизические свойства стеклонаполненных полифениленсульфидов и их устойчивость к внешним воздействуюшим и специиальным факторам.

Ключевые слова: стеклонаполненный полифениленсульфид, свойства, устойчивость, внешние воздействия, старение.

\section{BULK PROPERTIES AND APPLICATION OF GLASS FIBER FILLED POLYPHENYLENESULFIDE}

\author{
A.V.Samoryadov ${ }^{1}$, V.B. Ivanov ${ }^{2}$, E.V.Kalugina ${ }^{3}$ \\ ${ }^{1} 65$ Profsoyuznaya Street, 117997, Moscow, Russia. Interdepartment Center of Analytical Research in Physics, \\ Chemistry, and Biology, Presidium of Russian Academy of Sciences. \\ 24 Kosygina Str., Building 1, 119991, Moscow, Russia. Semenov Institute of Chemical Physics, Russian Academy \\ of Sciences. \\ ${ }^{3}$ 14, Generala Dorokhova str., 119530, Moscow, Russia. Group POLYPLASTIC, LLC, Moscow.
}

Thermal, physico-mechanical, electro-, thermophysical properties of glass fiber filled polyphenylene sulfides are investigated and their resistance to external acting and special factorss is established.

Key words: glass fiber filled Polyphenylene sulfide, properties, external action, ageing. 
Повышение требований к эксплуатационным характеристикам разрабатываемых изделий практически всех отраслей промышленности, их технологичности и габаритно-массовым характеристикам, обусловили потребность в высокотехнологичных пластмассах с существенно улучшенными технологическими и эксплуатационными характеристиками. В полной мере этим требованиям отвечают полимерные материалы на основе высокотермостойких термопластов (ВТT), таких как полиэфиркетоны, полиэфиримиды, полифениленсульфиды и их применение стало основной мировой тенденцией современной индустрии пластмасс.

Композиционные материалы на основе ВTT, благодаря высокой технологичности, обеспечивающей их переработку высокопроизводительными методами литья под давлением и экструзии и способности эксплуатироваться до $200-250{ }^{\circ} \mathrm{C}$ уже нашли широкое применение в производстве высоконагруженных изделий аэрокосмической, военной, автомобильной, электротехнической, электронной, автомобильной, приборостроительной и др. видов техники.

Рост производства и потребления ВТТ составляет порядка $10 \%$ в год [1-3], что более, чем вдвое опережает мировое производство пластмасс. При этом, наибольшим спросом и темпами роста объемов производства и применения характеризуются полифениленсульфиды (ПФС) благодаря уникальному сочетанию технологических и эксплуатационных свойств: высокая прочность, твердость, жесткость, низкая ползучесть, негорючесть, отличные электроизоляционные свойства, гидролитическая и химическая стойкость, в том числе, к автомобильному и авиационному топливу, высокая стойкость к климатическим факторам, УФ- и $\gamma$-излучению и минимальная проницаемость для большинства жидкостей и газов. Доступность сырья, относительная простота синтеза и низкая стоимость, предопределили бурное развитие ПФС, особенно в юго-восточной Азии, где темпы роста составляют $30-40 \%$ в год [2-7].

В настоящее время материалы на основе ПФС производят более 20 компаний разных стран под торговыми наименованиями: Ryton (ChevronPhillips, CPC), Fortron (Celanese, Ticona, Kureha, Polyplastics), Torelina (Toray, Япония), PPS (DIC Corp., Япония), Tedur (Bayer - ныне Albis Plastics), Craston (Ciba-Geigy), Primef (Solvay), и др., а марочный ассортимент превышает 100 наименований $[3,4,6-8]$. В 2012 г. мировой объем потребления композиций на основе ПФС превысил 135 тыс. тонн [7, 8], а уже в 2015 г. их производство достигло 180 тыс. тонн, что в денежном выражении (поряд- ка 3,0 млрд. евро) обогнало многие крупнотоннажные полимеры. Прогнозируемый объем производства материалов на основе ПФС в 2020 г. составляет 250 тыс. тонн.

Основными потребителями литьевых пластиков на основе ПФС в мире являются электротехника и электроника, автомобильная и аэрокосмическая отрасли, военная техника и др. динамично развивающиеся сектора экономики $[1,3,4,6,8-11]$.

Следует отметить, что системные исследования по ПФС проводились в СССР в 1970-1980 годы в Институте элементоорганических соединений имени А.Н. Несмеянова АН СССР [12-16] и даже были начаты работы по освоению опытного производства ПФС на НПО «Карболит» (г. Кемерово), но с развалом СССР все исследования и работы по ПФС были прекращены и производство ПФС в РФ до настоящего времени отсутствует.

В последние годы интерес в России к материалам на основе ПФС значительно возрос и научно-исследовательскими организациями, такими как ФГУП «ВИАМ» [17], МЦАИ РАН [17-21], НПП «Полипластик» [18-22], ФГУП «ЦНИИ КМ «ПРОМЕТЕЙ» $[23,24]$ проводятся работы по исследованиям в данной области, результаты которых уже реализованы в опытном и опытно-промышленном производствах:

- ФГУП «ЦНИИ КМ «ПРОМЕТЕЙ» освоило производство и применяет антифрикционный теплостойкий материал УПФС на основе полифениленсульфида марки Fortron и углеродной ткани;

- НПП «Полипластик» в 2018 г. освоил производство материала композиционного полимерного на основе полифениленсульфида марки ПФС CВ40-1, разработанного МЦАИ РАН, и литьевых стеклонаполненных материалов на основе ПФС марок АРМОТЕН и ТЕРМОРАН [25].

Анализ марочного ассортимента материалов на основе ПФС [18-22] показывает, что основное место занимают литьевые композиции с 40 масс.\% содержанием стекловолокна, применяемые в качестве высокопрочных конструкционных материалов: некоторые свойства стеклонаполненных ПФС ведущих мировых производителей приведены в таблице 1.

Стеклонаполненные композиции ПФС с меньшим содержанием стекловолокна (30 масс.\% и менее) имеют ограниченное применение, так как уровень их прочностных свойств ниже, чем у композиций с 40 масс.\% наполнением, а стоимость выше.

Композиции с более высокой степенью наполнения, в основном, стекломинералонаполненные на 60-70 масс.\%, характеризуются очень высокой жесткостью (модуль упругости составляет 17000 
Физико-механические свойства стеклонаполненных ПФС [9, 26-29]

\begin{tabular}{|c|c|c|c|c|c|c|c|c|}
\hline \multirow[b]{2}{*}{ №№ } & \multicolumn{2}{|c|}{ Характеристика материала } & \multirow{2}{*}{$\begin{array}{c}\text { Прочность } \\
\text { при } \\
\text { разрыве, } \\
\sigma_{\text {p }}, \text { МПа }\end{array}$} & \multirow{2}{*}{$\begin{array}{c}\text { Модуль } \\
\text { упругости } \\
\text { при разрыве } \\
\text { МПа }\end{array}$} & \multirow{2}{*}{ 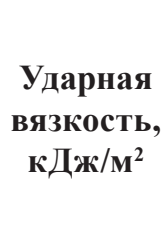 } & \multirow{2}{*}{$\begin{array}{c}\text { Тепло- } \\
\text { стойкость } \\
\text { при изгибе } \\
{ }^{\circ} \mathrm{C}\end{array}$} & \multirow{2}{*}{$\begin{array}{c}\text { Удельное } \\
\text { электро- } \\
\text { сопроти- } \\
\text { вление, } \\
\text { Ом·м }\end{array}$} & \multirow{2}{*}{$\begin{array}{c}\text { Электри- } \\
\text { ческая } \\
\text { проч- } \\
\text { ность, } \\
\text { кВ/мм }\end{array}$} \\
\hline & $\begin{array}{c}\text { Наименование, } \\
\text { производитель, } \\
\text { страна }\end{array}$ & марка & & & & & & \\
\hline \multirow[t]{4}{*}{1.} & Ryton ${ }^{\circledR}$ & BR 111* & 159 & 12300 & 24 & 260 & $10^{13}$ & 17,7 \\
\hline & Chevron-Phillips, & $\mathrm{R}-4$ & 165 & 13700 & 25 & 260 & $10^{13}$ & 19,7 \\
\hline & США & $\mathrm{R}-4-240 \mathrm{BL}$ & 165 & 14500 & 40 & 265 & $10^{13}$ & 21,7 \\
\hline & & R-4-270NA & 190 & 14500 & 45 & 265 & $10^{13}$ & 20 \\
\hline \multirow[t]{4}{*}{2.} & Fortron ${ }^{\circledR}$ & 1140L4 & 195 & 12200 & 53 & 270 & $10^{13}$ & 28 \\
\hline & Celanese, Ticona, & $1140 \mathrm{E} 7$ & 150 & 14700 & 28 & 270 & $10^{13}$ & 28 \\
\hline & Германия & ICE 504L & 170 & - & 51 & 262 & $10^{13}$ & 30 \\
\hline & & MT9140L4 & 190 & 13800 & 48 & 270 & $10^{13}$ & 28 \\
\hline \multirow[t]{3}{*}{3.} & Tedur ${ }^{\circledR}$ & L4510-1 & 180 & - & 45 & 260 & $10^{13}$ & 25 \\
\hline & Albis Plastics, & L9107-1U & 190 & - & 45 & 275 & $10^{13}$ & 25 \\
\hline & США-Канада & L 9107-7 & 200 & & 45 & 275 & $10^{13}$ & 25 \\
\hline \multirow[t]{5}{*}{4.} & PPS, & PPS FZ-1140 & 180 & 15000 & 36 & 265 & $10^{13}$ & 16 \\
\hline & DIC, Япония & PPS FZ-1140B2 & 170 & 15000 & 40 & 265 & $10^{13}$ & 16 \\
\hline & & PPS FZ-2140 & 180 & 14000 & 46 & 265 & $10^{13}$ & 16 \\
\hline & & PPS FZ-2140A1 & 190 & 15000 & 51 & 270 & $10^{13}$ & 16 \\
\hline & & PPS FZ-240 & 165 & 11500 & 53 & 265 & $10^{13}$ & 16 \\
\hline \multirow[t]{5}{*}{5.} & PPS Torelina, & A504CX1B & 199 & 14500 & 55 & 260 & $10^{13}$ & 24 \\
\hline & Toray Industries, & A504CX90 & 200 & 15500 & 55 & 260 & $10^{13}$ & 24 \\
\hline & Япония & A504CX95 & 190 & 15500 & 45 & 265 & $10^{13}$ & 25 \\
\hline & & A504FG1 & 165 & 15000 & 30 & 260 & $10^{13}$ & 22 \\
\hline & & A674M2* & 150 & 12000 & 57 & 260 & $10^{13}$ & 24 \\
\hline
\end{tabular}

* модифицированная ударопрочная композиция

21000 МПа), но имеют низкую текучесть и ударную вязкость (20-25 кДж/м²), вследствие чего применяются, в основном, для изготовления толстостенных деталей, преимущественно, электротехнического назначения.

С 2018 г. в России освоено производство стеклонаполненных композиционных материалов на основе ПФС: марочный ассортимент материалов товарного знака Армотен (таблица 2) достаточно широк и охватывает основные области практического применения. Материалы товарного знака ТЕРМОРАН (таблица 3) представлены 2-мя марками: высокопрочный стеклонаполненный полифениленсульфид марки ТЕРМОРАН ПФС СВ-40 и марки ТЕРМОРАН ПФС СВ-40УП - его ударопрочный аналог. Обе марки материала производятся неокрашенными или окрашенными в массе в черный цвет. Материалы ТЕРМОРАН сертифицированы и паспортизованы.

Материал композиционный полимерный марки ПФС СВ 40-1 представляет собой полифени- ленсульфид, наполненный 40 масс.\% стекловолокна, а также целевыми добавками, характеризуется практическим отсутствием ионов хлора и предназначен для изготовления изделий электронной, электротехнической и др. специальной техники.

Анализ данных таблиц 1-3 показывает, что по уровню прочностных, электро- и теплофизических характеристик производимые в РФ стеклонаполненные материалы не уступают лучшим зарубежным аналогам, как по базовым, так и по модифицированным ударопрочным композициям.

Безусловно, сравнительная оценка уровня исходных (базовых) характеристик материалов важна и дает достаточно полное представление об уровне достижений в данной области, но вместе с тем, этих данных недостаточно для определения возможности применения указанных материалов в конкретных изделиях с заданными условиями эксплуатации.

С этой точки зрения, по импортным материалам конкретных данных и сведений в коньюнк- 
Физико-механические свойства композиций стеклонаполненного (40 масс.\%) ПФС марки Армотен

\begin{tabular}{|c|c|c|c|c|c|c|}
\hline Наименование показателя & $\begin{array}{c}\text { Метод } \\
\text { испытаний }\end{array}$ & $\begin{array}{c}\text { Армотен } \\
\text { СВ } 40\end{array}$ & $\begin{array}{c}\text { Армотен } \\
\text { CВ 30 }\end{array}$ & $\begin{array}{c}\text { Армотен } \\
\text { СВ } 30-У П\end{array}$ & $\begin{array}{c}\text { Армотен } \\
\text { СВ } 40 \text {-УП }\end{array}$ & $\begin{array}{c}\text { Армотен } \\
\text { СВ МН } 60\end{array}$ \\
\hline 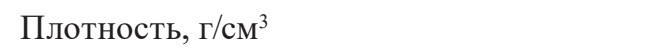 & ГОСТ 15139 & 1,66 & 1,58 & 1,51 & 1,62 & 1,91 \\
\hline Прочность при разрыве, МПа & ГОСТ 11262 & 206 & 181 & 166 & 196 & 158 \\
\hline Модуль упругости при растяжении, МПа & ГОСТ 9550 & 16693 & 12880 & 10900 & 15640 & 24770 \\
\hline $\begin{array}{l}\text { Изгибающее напряжение } \\
\text { при максимальной нагрузке, МПа }\end{array}$ & ГОСТ 4648 & 302 & 259 & 246 & 289 & 258 \\
\hline Модуль упругости при изгибе, МПа & ГОСТ 4648 & 13100 & 10440 & 10200 & 12540 & 19500 \\
\hline $\begin{array}{l}\text { Ударная вязкость по Шарпи образца } \\
\text { без надреза (в ребро), кДж/м² }\end{array}$ & ГОСТ 4647 & 56 & 43 & 68 & 62 & 25 \\
\hline $\begin{array}{l}\text { Температура изгиба под нагрузкой } \\
1,80 \text { Мпа, }{ }^{\circ} \mathrm{C}\end{array}$ & ГОСТ 12021 & 272 & 267 & 263 & 269 & 275 \\
\hline $\begin{array}{l}\text { Тангенс угла диэлектрических потерь, } \\
\text { при частоте } 1 \text { МГц }\end{array}$ & ГОСТ 22372 & 0,002 & 0,002 & 0,004 & 0,003 & 0,002 \\
\hline Диэлектрическаяпроницаемость & ГОСТ 22372 & 4 & 4 & 4 & 4 & 5 \\
\hline $\begin{array}{l}\text { Удельное объемное электрическое } \\
\text { сопротивление, Ом·м }\end{array}$ & ГОСТ 6433.3 & $6 \cdot 10^{14}$ & $6 \cdot 10^{14}$ & $6 \cdot 10^{14}$ & $6 \cdot 10^{14}$ & $2 \cdot 10^{14}$ \\
\hline $\begin{array}{l}\text { Удельное поверхностное электрическое } \\
\text { сопротивление, Ом }\end{array}$ & ГОСТ 6433.3 & $8 \cdot 10^{16}$ & $8 \cdot 10^{16}$ & $8 \cdot 10^{16}$ & $8 \cdot 10^{16}$ & $2 \cdot 10^{16}$ \\
\hline Электрическая прочность (1 мм), кВ/мм & ГОСТ 6433.3 & 34 & 30 & 27 & 30 & 27 \\
\hline
\end{tabular}

турной, научно-технической и рекламной информации по их стойкости к эксплуатационным, внешним воздействующим, а тем более специальным факторам, практически нет: как правило, информация ограничивается общими фразами вроде «материалы характеризуются высокой стойкостью к воздействию температуры, гидролизу, климатическим и др. внешним воздействиям.

Исходя из изложенного, в данной статье приведены результаты исследований основных свойств в широком диапазоне температур и стойкости отечественных стеклонаполненных полифениленсульфидов марок ТЕРМОРАН ПФС СВ-40, ТЕРМОРАН ПФС СВ-40УП и ПФС СВ 40-1 к внешним воздействующим, специальным и эксплуатационным факторам. Испытания материалов проводили по стандартизованным методикам, указанным в таблицах.

\section{Свойства материалов в широком диапазоне температур}

Показатели прочностных характеристик материалов марки ТЕРМОРАН в широком интервале температур имеют идентичные закономерности изменения свойств от температуры испытаний между собой и маркой ПФС СВ 40-1: в области низких температур возрастает жесткость и прочность, а с повышением температуры испытаний повышается эластичность материала (таблица 4).

Разрушение материалов при растяжении хрупкое при малых величинах деформации, что характерно для наполненных полимерных композиционных материалов: кривые «напряжение-деформация» обеих марок материала приведены на рис. 1.

Прекрасные электроизоляционные свойства исследованных материалов (таблица 3) сохраняются во всем диапазоне температур эксплуатации. Электрическая прочность материалов составляет от 28 до 32 кВ/мм, что выше аналогичного показателя для широко применяемых конструкционных термопластов и практически не изменяется при повышении температуры до $220^{\circ} \mathrm{C}$.

Удельное объемное электрическое сопротивление при нормальных условиях составляет $10^{15}$ $10^{16}$ Ом·см, но с повышением температуры выше температурной области стеклования ПФС, составляющей от 90 до $120^{\circ} \mathrm{C}$, снижается примерно на 2 порядка.

Диэлектрическая проницаемость практически не зависит от температуры и составляет 3,5-4,5.

Тангенс угла диэлектрических потерь при нормальных условиях составляет $0,002-0,003$ при частоте $10^{6}$ Гц, но имеет тенденцию к небольшому 
Свойства стеклонаполненных полифениленсульфидов

\begin{tabular}{|c|c|c|c|c|c|}
\hline \multirow[b]{2}{*}{$\begin{array}{l}\text { № } \\
\text { п1/II }\end{array}$} & \multirow[b]{2}{*}{ Наименование показателя качества } & \multirow{2}{*}{$\begin{array}{c}\text { Метод } \\
\text { испытаний }\end{array}$} & \multicolumn{3}{|c|}{ Значение параметра для марки } \\
\hline & & & $\begin{array}{l}\text { TЕPМОРАН } \\
\text { ПФС СB-40 }\end{array}$ & $\begin{array}{l}\text { ТЕРМОРАН } \\
\text { ПФС СВ-40УП }\end{array}$ & $\begin{array}{c}\text { ПФС СВ } \\
40-1\end{array}$ \\
\hline 1 & Прочность при разрыве, МПа & ГОСТ 11262 & 205 & 186 & 187 \\
\hline 2 & Модуль упругости при растяжении, МПа & ГОСТ 9550 & 15960 & 14500 & 15730 \\
\hline 3 & $\begin{array}{l}\text { Изгибающее напряжение при максимальной } \\
\text { нагрузке, МПа }\end{array}$ & ГОСТ 4648 & 291 & 278 & 270 \\
\hline 4 & Модуль упругости при изгибе, МПа & ГОСТ 4648 & 14100 & 12620 & 12930 \\
\hline 5 & $\begin{array}{l}\text { Ударная вязкость по Шарпи образца } \\
\text { без надреза }\left(23^{\circ} \mathrm{C}\right) \text { в ребро, кДж/м }{ }^{2}\end{array}$ & ГОСТ 4647 & 53,0 & 63,0 & 55 \\
\hline 6 & Водопоглощение за 24 часа, \% & ГОСТ 4650 & 0,02 & 0,02 & 0,02 \\
\hline 7 & 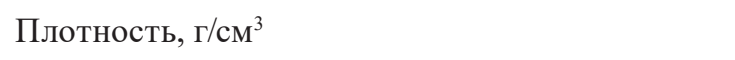 & ГОСТ 15139 & 1,65 & 1,60 & 1,66 \\
\hline 8 & $\begin{array}{l}\text { Удельное объемное электрическое } \\
\text { сопротивление, Ом·см }\end{array}$ & ГОСТ 6433.2 & $6 \cdot 10^{16}$ & $6 \cdot 10^{16}$ & $4 \cdot 10^{16}$ \\
\hline 9 & $\begin{array}{l}\text { Удельное поверхностное электрическое } \\
\text { сопротивление, Ом }\end{array}$ & ГОСТ 6433.2 & $4 \cdot 10^{16}$ & $10^{16}$ & $4 \cdot 10^{16}$ \\
\hline 10 & Электрическая прочность, кВ/мм, & ГОСТ 6433.3 & 28 & 32 & 31 \\
\hline 11 & $\begin{array}{l}\text { Тангенс угла диэлектрических потерь } \\
\text { при частоте } 10^{6} Г ц\end{array}$ & ГОСТ 22372 & 0,0024 & 0,0026 & 0,003 \\
\hline 12 & $\begin{array}{l}\text { Диэлектрическая проницаемость при частоте } \\
10^{6} \text { Гц }\end{array}$ & ГОСТ 22372 & 4,0 & 3,9 & 4,0 \\
\hline 13 & Температура изгиба под нагрузкой $1,8 \mathrm{MПа,}{ }^{\circ} \mathrm{C}$ & ГОСТ 12021 & 271 & 265 & 266 \\
\hline 14 & $\begin{array}{l}\text { Коэффициент линейного теплового } \\
\text { расширения, град }{ }^{-1}\end{array}$ & ГОСТ 32618.2 & $14 \cdot 10^{-6}$ & $15 \cdot 10^{-6}$ & $15 \cdot 10^{-6}$ \\
\hline 15 & Теплопроводность, Вт/м·К & ISO $2207-2$ & 0,36 & 0,35 & 0,36 \\
\hline 16 & Стойкость к горению (категория) & ГОСТ 28157 & ПВ-0 & ПВ-0 & ПВ-0 \\
\hline 17 & Стойкость к воздействию нагретой проволоки & ГОСТ 27483 & 960 & 960 & 960 \\
\hline 18 & Грибостойкость, балл & ГОСТ 9.049 & $0-1$ & $0-1$ & $0-1$ \\
\hline
\end{tabular}

Таблица 4 Свойства стеклонаполненных полифениленсульфидов марки ТЕРМОРАН при различных температурах [30]

\begin{tabular}{|c|c|c|c|c|c|c|}
\hline \multirow{3}{*}{$\begin{array}{c}\text { Температура } \\
\text { испытаний, } \\
{ }^{\circ} \mathbf{C}\end{array}$} & \multicolumn{6}{|c|}{ Значения параметров для марки материала } \\
\hline & \multicolumn{3}{|c|}{ ТЕРМОРАН ПФС СВ-40 } & \multicolumn{3}{|c|}{ ТЕРМОРАН ПФС СВ-40УП } \\
\hline & $\begin{array}{c}\mathbf{E}_{\text {p }} \\
\text { МП̆ }\end{array}$ & $\begin{array}{c}\sigma_{\mathrm{pp}} \\
\text { МПа }\end{array}$ & $\begin{array}{c}\varepsilon_{\mathrm{pp}} \\
\% \\
\%\end{array}$ & $\begin{array}{c}\mathbf{E}_{\mathrm{p}} \\
\text { МПа }\end{array}$ & $\begin{array}{c}\boldsymbol{\sigma}_{\mathrm{pp}} \\
\mathbf{M}\end{array}$ & $\begin{array}{c}\varepsilon_{\mathrm{pp}}, \\
\%\end{array}$ \\
\hline-60 & 20013 & 234 & 1,88 & 18525 & 232 & 1,90 \\
\hline-40 & 18633 & 218 & 1,90 & 17640 & 211 & 2,07 \\
\hline 0 & 16851 & 202 & 1,90 & 15342 & 196 & 1,93 \\
\hline+23 & 15670 & 200 & 1,88 & 13247 & 185 & 1,99 \\
\hline+40 & 15294 & 189 & 1,92 & 14381 & 179 & 1,91 \\
\hline+80 & 14386 & 157 & 1,95 & 12794 & 144 & 2,11 \\
\hline+130 & 6869 & 85,5 & 2,91 & 6140 & 79,5 & 3,19 \\
\hline+180 & 5604 & 66,4 & 2,77 & 5176 & 66,1 & 3,79 \\
\hline+200 & 5174 & 58,2 & 3,11 & 4866 & 57,8 & 3,90 \\
\hline+240 & 4716 & 40,1 & 1,42 & 4472 & 43,0 & 2,43 \\
\hline
\end{tabular}


Терморан ПФС CВ-40

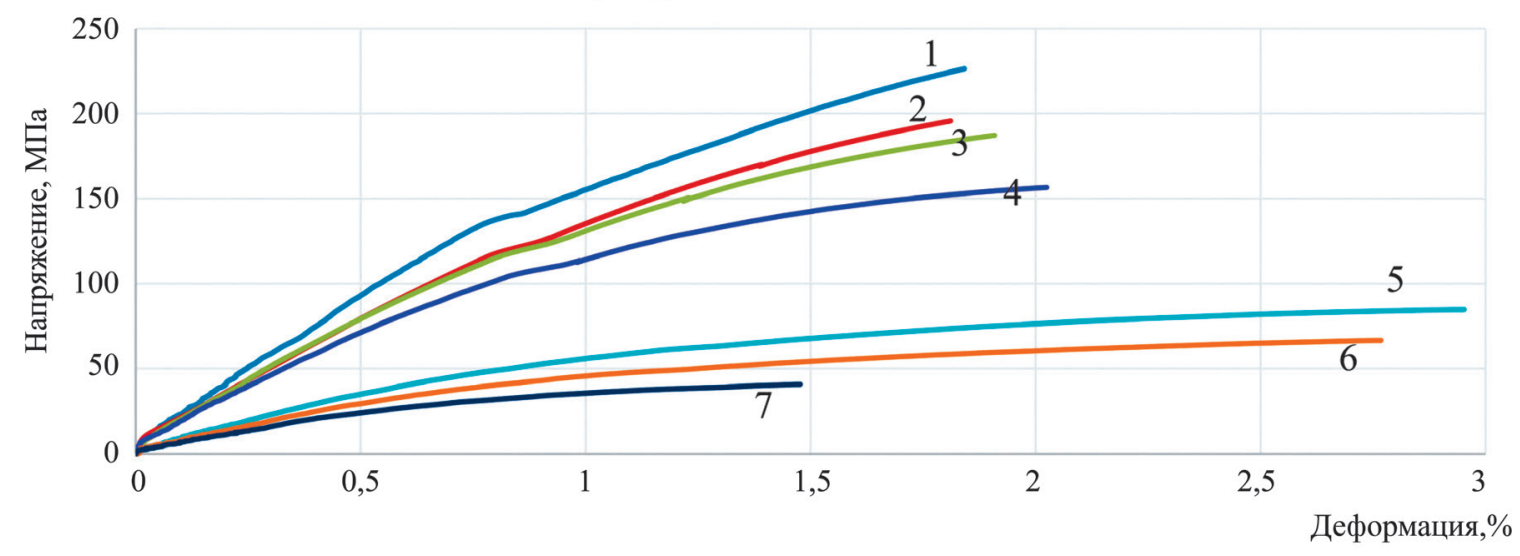

Терморан ПФС СВ-40 УП

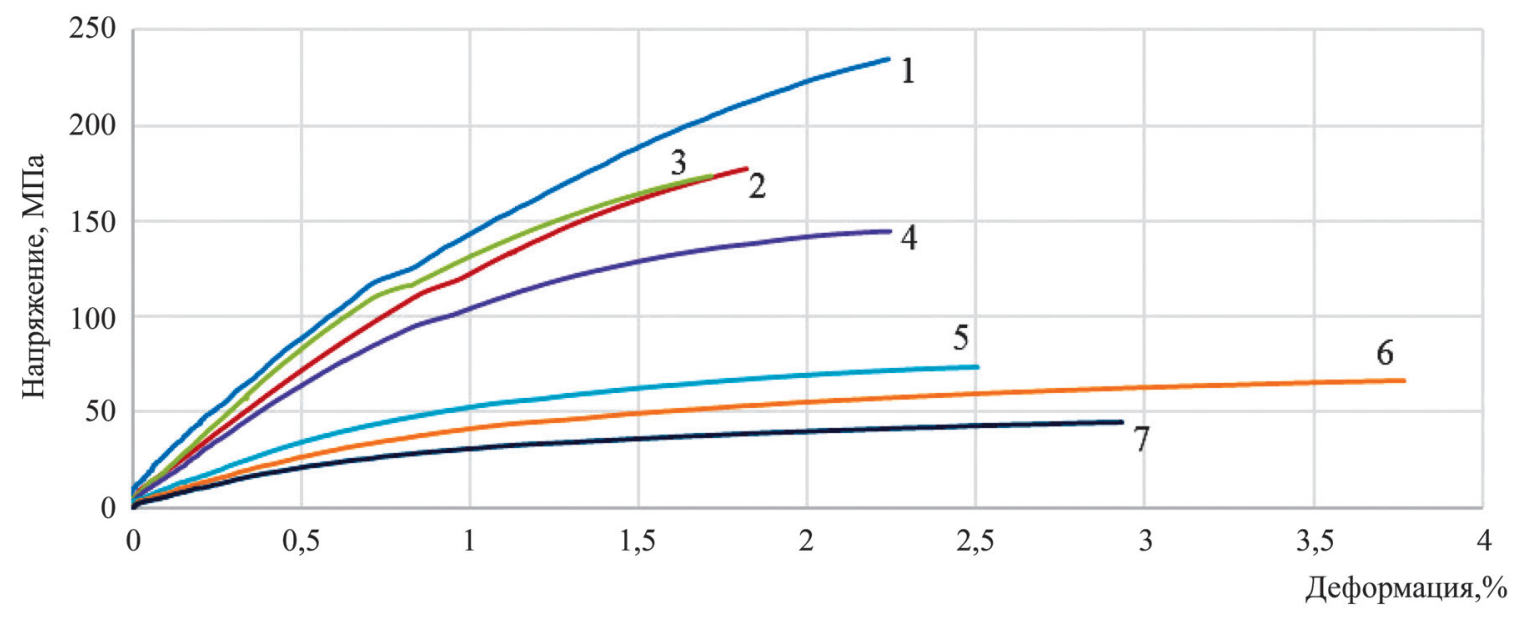

Рис. 1. Кривые «напряжение-деформация» стеклонаполненного полифениленсульфида МароК ТЕРМОРАН ПФС СВ-40 и ТЕРМОРАН ПФС СВ-40УП

$\mathbf{1}--40{ }^{\circ} \mathrm{C} ; \mathbf{2}-23{ }^{\circ} \mathrm{C} ; \mathbf{3}-40{ }^{\circ} \mathrm{C} ; \mathbf{4}-80{ }^{\circ} \mathrm{C} ; \mathbf{5}-130{ }^{\circ} \mathrm{C} ; \mathbf{6}-180{ }^{\circ} \mathrm{C} ; \mathbf{7}-240{ }^{\circ} \mathrm{C}$

росту при уменьшении частоты и повышении температуры испытаний.

Теплопроводность материалов составляет 0,36 и $0,35 \mathrm{BT} / \mathrm{M} \cdot \mathrm{K}$ и незначительно повышается при нагревании до $230-240{ }^{\circ} \mathrm{C}$.

Стеклонаполненные полифениленсульфиды в широком температурном диапазоне имеют достаточно низкий и стабильный показатель коэффициента линейного теплового расширения (КЛТР), близкий по своему значению к цветным металлам (латунь, бронза и т.д.), что обеспечивает получение прочных и герметичных армированных металлической арматурой конструкций. Небольшой перегиб в диапазоне $90-110{ }^{\circ} \mathrm{C}$ на термомеханической кривой (рис. 2) соответствует области стеклования ПФС.

Стеклонаполненные полифениленсульфиды (таблица 3) являются негорючими материалами, ввиду природной негорючести полимерной матрицы (кислородный индекс полифениленсульфида = 48) без введения замедлителей горения (антипиренов) и имеют высшую категорию стойкости пластмасс к горению (таблица 1) - категория ПВ-0 (V-0 по UL 94).

Испытаниями на пожароопасность установлена стойкость к воздействию нагретой проволоки в $960{ }^{\circ} \mathrm{C}$ (таблица 3), что позволяет использовать материалы для оборудования под постоянной нагрузкой для эксплуатации в жестких условиях.

Стеклонаполненные полифениленсульфиды всех марок (таблица 3) характеризуются высокой грибостойкостью: грибостойкость при испытаниях по методу 1 (чистые образцы) ГОСТ 9.049 составляет 0 баллов, а по методу 2 (зараженные образцы) ГОСТ 9.049 - 1 балл. 


\section{Стойкость к внешним воздействующим факторам}

Влаго- и водостойкость

Стеклонаполненные полифениленсульфиды характеризуются очень низким влагопоглощением, составляющим 0,02 масс.\% в соответствии с ГОСТ 4650 после 24 часовой выдержки в воде при комнатной температуре.

Испытания материалов по ГОСТ 10315 на влагостойкость выдержкой образцов (диски диаметром $(50 \pm 2)$ мм и толщиной $(3,0 \pm 0,2)$ мм) в климатической камере в атмосфере воздуха с относительной влажностью $(93 \pm 2) \%$ и температуре $(23+2){ }^{\circ} \mathrm{C}$, а на водостойкость - в дистиллированной воде при температуре $(23+0,5){ }^{\circ} \mathrm{C}$ показали (таблицы 5-6), что геометрические размеры и масса образцов в результате экспозиции в течение 12 месяцев практически не изменились: изменение массы составляет всего $0,032 \%$, а линейных размеров - не превышает $0,025 \%$, что укладывается в требования КД для высокоточных деталей (класс f по ГОСТ 30893.1). В таблицах 5-6 приведены результаты испытаний только для марки ТЕРМОРАН ПФС CВ-40, т.к. они совпадают с результатами ис- пытаний материалов марок ТЕРМОРАН ПФС СВ40УП и ПФС СВ 40-1.

\section{Стойкость к воздействию изменения температурь}

Применительно к условиям эксплуатации информативным показателем стойкости материалов является стойкость к воздействию изменения температуры или термоциклостойкость, которая воспроизводит эксплуатационные, сезонные и суточные перепады температур. Исходя из того, что изделия и техника различных отраслей промышленности может эксплуатироваться в любом из климатических районов, описанных в ГОСТ 15150, с учетом дополнительных увеличений температуры изделий за счет нагрева солнечными лучами, нами был принят для испытаний диапазон изменения температуры с предельными значениями минус 70 и плюс $90{ }^{\circ} \mathrm{C}$. Испытания стеклонаполненных ПФС на стойкость к воздействию изменения температуры проводили по ГОСТ РВ 20.57.416 (метод 205-1) путем последовательной выдержки в камерах тепла и холода при температурах $-70{ }^{\circ} \mathrm{C}$ и $+90^{\circ} \mathrm{C}$ по 4 часа при каждой температуре. Общее количество циклов составило 25.

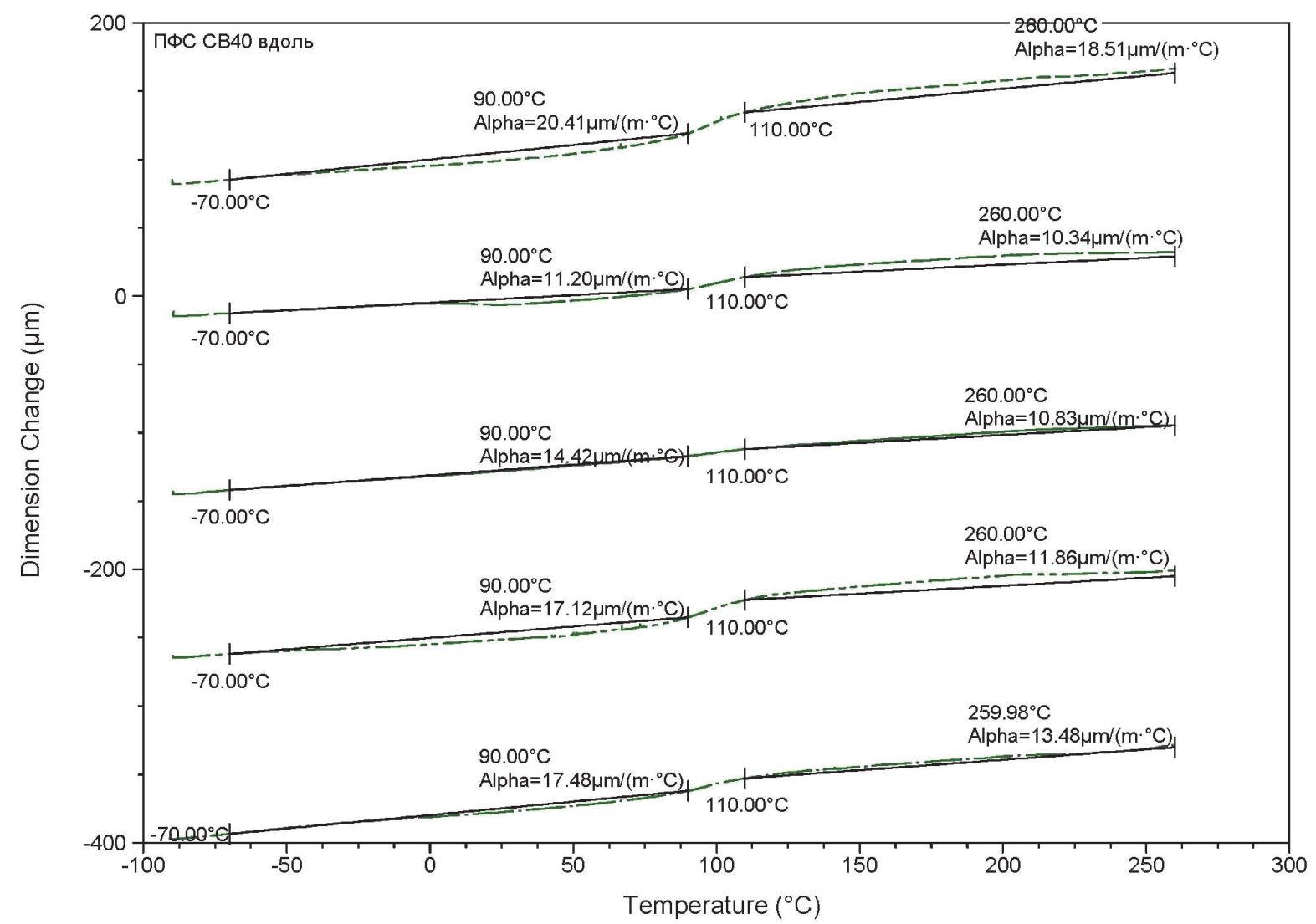

Рис. 2. Зависимость КЛТР стеклонаполненного полифениленсульфида марки ТЕРМОРАН ${ }^{\mathrm{TM}}$ ПФС СВ-40 от температуры 


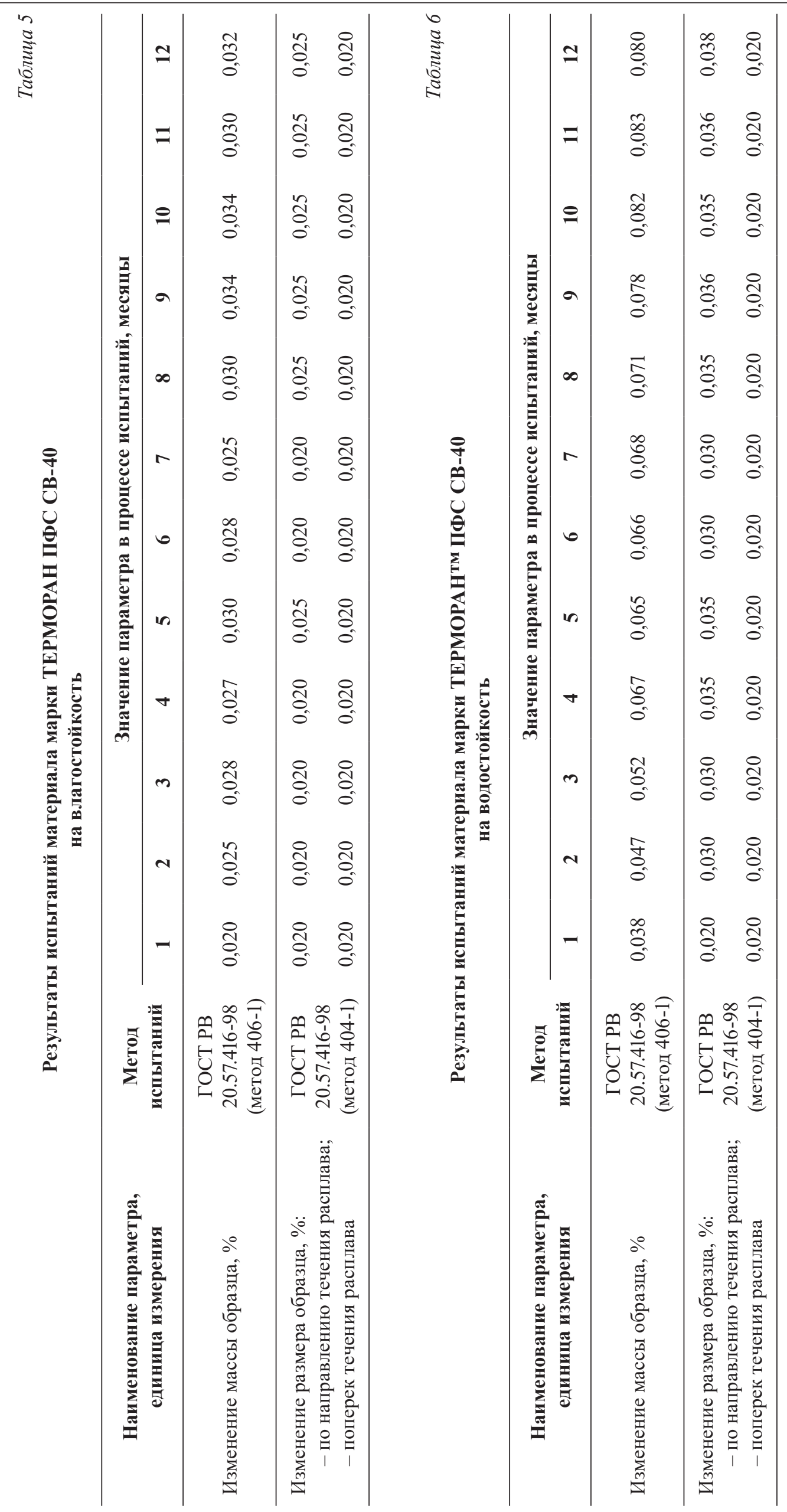


Результаты испытаний стеклонаполненных полифениленсульфидов на стойкость к воздействию изменения температуры в диапазоне от минус 70 до $90^{\circ} \mathrm{C}$

\begin{tabular}{|c|c|c|c|c|c|}
\hline \multirow{2}{*}{$\begin{array}{c}\text { Наименование показателя, единица } \\
\text { измерения }\end{array}$} & \multirow{2}{*}{$\begin{array}{c}\text { Метод } \\
\text { испытаний }\end{array}$} & \multicolumn{2}{|c|}{ ТЕРМОРАН ПФС СВ-40 } & \multicolumn{2}{|c|}{ ПФС СВ 40-1 } \\
\hline & & $\begin{array}{c}\text { до } \\
\text { испытаний }\end{array}$ & $\begin{array}{c}\text { после } \\
\text { испытаний }\end{array}$ & $\begin{array}{c}\text { до } \\
\text { испытаний }\end{array}$ & $\begin{array}{c}\text { после } \\
\text { испытаний }\end{array}$ \\
\hline Прочность при разрыве, МПа & ГОСТ 11262 & 192 & 183 & 185 & 183 \\
\hline Модуль упругости при растяжении, МПа & ГОСТ 9550 & 15969 & 15686 & - & - \\
\hline $\begin{array}{l}\text { Изгибающее напряжение } \\
\text { при максимальной нагрузке, МПа }\end{array}$ & ГОСТ 4648 & 285,4 & 287,1 & 271 & 273 \\
\hline Ударная вязкость по Шарпи, кДж/м² & ГОСТ 4647 & 55,8 & 54,6 & 61 & 60 \\
\hline $\begin{array}{l}\text { Удельное объемное электрическое } \\
\text { сопротивление, Ом·см }\end{array}$ & ГОСТ 6433.2 & $6 \cdot 10^{16}$ & $6 \cdot 10^{16}$ & $6 \cdot 10^{16}$ & $6 \cdot 10^{16}$ \\
\hline Электрическая прочность, кВ/мм & ГОСТ 6433.3 & 34 & 34 & - & - \\
\hline
\end{tabular}

Как видно из данных таблицы 7, физико-механические и электрофизические свойства материалов после испытаний практически не изменились и находятся в пределах требований технической документации.

Применительно к условиям эксплуатации изделий авиакосмической и др. специальной техники был выбран температурный диапазон изменения температуры с предельными значениями минус 150 и плюс $150{ }^{\circ} \mathrm{C}$. При испытаниях выдержка при каждой температуре в цикле составляла не менее 10 минут, а общее количество циклов - 100.

Как видно из данных таблицы 8, показатели и характеристики стеклонаполненного ПФС остались практически на исходном уровне, что свидетельствует о его высокой термоциклостойкости.

Испытания по оценке стойкости к воздействию соляного тумана проводились по ГОСТ PB 20.57.306, п 5.12: при испытаниях образцы подвергались в камере соляного тумана модели CORROSIONBOX 1000 Не воздействию соляного тумана дисперсностью 1 - 10 мкм (95 \% капель) и водностью $2-3$ г/м $\mathrm{M}^{3}$, температура в испытательной камере $(55 \pm 2){ }^{\circ} \mathrm{C}$, продолжительность воздей- ствия - 7 суток. Как видно из результатов испытаний (таблица 9) материалы всех марок стойки к воздействию соляного тумана.

Стеклонаполненные полифениленсульфиды всех марок (таблица 3) также обладают высокой стойкостью к солнечному излучению (таблица 10). Испытания на стойкость к солнечному излучению проводили по ГОСТ РВ 20.57-306 (п. 5.10 метод 1): камера испытательная световая /везерометр/ модели Q-Sun Xe-3HSC, температура в испытательной камере $(+45 \pm 2)^{\circ} \mathrm{C}$, время воздействия -5 суток.

Отметим, что модифицированный стеклонаполненный материал (ТЕРМОРАН ПФС СВ-40УП) обладает повышенной устойчивостью к солнечному излучению. Еще большей стойкостью характеризуется материал, окрашенный в массе в черный цвет.

Отметим также, что при воздействии солнечного излучения на стеклонаполненные полифениленсульфиды было обнаружено обратимое изменение их окраски [22], и подробно исследовано влияние условий фотоокисления и фотодеструкции на материалы различного композиционного состава $[31,32]$.

Таблица 8

Результаты испытаний стеклонаполненного полифениленсульфида марки ТЕРМОРАН ПФС СВ-40 на стойкость к воздействию изменения температуры в диапазоне от минус 150 до 150 C

Наименование показателя, единица измерения

Прочность при разрыве, МПа

Изгибающее напряжение при максимальной нагрузке, МПа

Прочность при сжатии, МПа
Метод испытаний

ГОСТ 11262

ГОСТ 4648

ГОСТ 4651
Значение показателя до испытаний после испытаний

\begin{tabular}{ll}
189,5 & 190,8 \\
286,2 & 293,2 \\
183,9 & 178,0 \\
\hline
\end{tabular}


Таблица 9

Результаты испытаний материалов на стойкость к соляному туману

\begin{tabular}{|c|c|c|c|c|c|c|c|}
\hline \multirow{3}{*}{$\begin{array}{c}\text { Наименование показателя, } \\
\text { единица измерения }\end{array}$} & \multirow{3}{*}{$\begin{array}{c}\text { Метод } \\
\text { испытаний }\end{array}$} & \multicolumn{6}{|c|}{ Марка стеклонаполненного полифениленсульфида } \\
\hline & & \multicolumn{2}{|c|}{$\begin{array}{c}\text { Терморан } \\
\text { ПФС СВ-40 }\end{array}$} & \multicolumn{2}{|c|}{ ПФС СВ 40-1 } & \multicolumn{2}{|c|}{$\begin{array}{c}\text { Терморан } \\
\text { ПФС СВ-40УП }\end{array}$} \\
\hline & & $1 *$ & $2 *$ & $1^{*}$ & $2 *$ & $1^{*}$ & $2 *$ \\
\hline Прочность при разрыве, МПа & ГОСТ 11262 & 201 & 186 & 185,0 & 177,0 & 186 & 187 \\
\hline $\begin{array}{l}\text { Модуль упругости при растяжении, } \\
\text { МПа }\end{array}$ & ГОСТ 9550 & 16100 & 15560 & 16407 & 16030 & 14500 & 14410 \\
\hline $\begin{array}{l}\text { Изгибающее напряжение } \\
\text { при максимальной нагрузке, МПа }\end{array}$ & ГОСТ 4648 & 291 & 293 & 271 & 263 & 278 & 272 \\
\hline Модуль упругости при изгибе, МПа & ГОСТ 4648 & 13700 & 13230 & 12930 & 13340 & 13620 & 12040 \\
\hline $\begin{array}{l}\text { Ударная вязкость по Шарпи образца } \\
\text { без надреза (в ребро), кДж/м² }\end{array}$ & ГОСТ 4647 & 54 & 54 & 50 & 45 & 63 & 58 \\
\hline $\begin{array}{l}\text { Удельное объемное электрическое } \\
\text { сопротивление, Ом·см }\end{array}$ & ГОСТ 6433.2 & $6 \cdot 10^{16}$ & $4 \cdot 10^{15}$ & $6 \cdot 10^{16}$ & $2 \cdot 10^{16}$ & $1 \cdot 10^{16}$ & $1 \cdot 10^{16}$ \\
\hline $\begin{array}{l}\text { Удельное поверхностное электрическое } \\
\text { сопротивление, Ом }\end{array}$ & ГОСТ 6433.2 & $6 \cdot 10^{16}$ & $2 \cdot 10^{16}$ & $6 \cdot 10^{16}$ & $2 \cdot 10^{16}$ & $6 \cdot 10^{14}$ & $6 \cdot 10^{16}$ \\
\hline Электрическая прочность, кВ/мм & ГОСТ 6433.3 & 34 & 34 & 32 & 33 & 32 & 34 \\
\hline
\end{tabular}

* 1 - значение параметра до испытаний, 2 - после испытаний.

Таблица 10

Результаты испытаний материалов на стойкость к солнечному излучению

\begin{tabular}{|c|c|c|c|c|c|c|c|}
\hline \multirow{3}{*}{$\begin{array}{c}\text { Наименование показателя, } \\
\text { единица измерения }\end{array}$} & \multirow{3}{*}{$\begin{array}{c}\text { Метод } \\
\text { испытаний }\end{array}$} & \multicolumn{6}{|c|}{ Марка стеклонаполненного полифениленсульфида } \\
\hline & & \multicolumn{2}{|c|}{$\begin{array}{c}\text { Терморан ПФС } \\
\text { СВ-40 }\end{array}$} & \multicolumn{2}{|c|}{ ПФС СВ 40-1 } & \multicolumn{2}{|c|}{$\begin{array}{c}\text { Терморан ПФС } \\
\text { СВ-40УП }\end{array}$} \\
\hline & & $1 *$ & 2* & $1 *$ & 2* & $1^{*}$ & $2 *$ \\
\hline Прочность при разрыве, МПа & ГОСТ 11262 & 201 & 187 & 185,0 & 170,2 & 186 & 185 \\
\hline Модуль упругости при растяжении, МПа & ГОСТ 9550 & 16100 & 15750 & 16407 & 16400 & 14500 & 14230 \\
\hline $\begin{array}{l}\text { Изгибающее напряжение } \\
\text { при максимальной нагрузке, МПа }\end{array}$ & ГОСТ 4648 & 291 & 279 & 271,0 & 262,8 & 278 & 274 \\
\hline Модуль упругости при изгибе, МПа & ГОСТ 4648 & 13700 & 13650 & 12930 & 12950 & 13620 & 12312 \\
\hline $\begin{array}{l}\text { Ударная вязкость по Шарпи образца } \\
\text { без надреза (в ребро), кДж/м² }\end{array}$ & ГОСТ 4647 & 54 & 42 & 50,0 & 39,3 & 63 & 58 \\
\hline $\begin{array}{l}\text { Удельное объемное электрическое } \\
\text { сопротивление, Ом·см }\end{array}$ & ГОСТ 6433.2 & $6 \cdot 10^{16}$ & $6 \cdot 0^{16}$ & $8 \cdot 10^{15}$ & $5 \cdot 10^{15}$ & $1 \cdot 10^{16}$ & $6 \cdot 10^{16}$ \\
\hline $\begin{array}{l}\text { Удельное поверхностное электрическое } \\
\text { сопротивление, Ом }\end{array}$ & ГОСТ 6433.2 & $6 \cdot 10^{14}$ & $2 \cdot 10^{16}$ & $6 \cdot 10^{16}$ & $6 \cdot 10^{16}$ & $6 \cdot 10^{14}$ & $1 \cdot 10^{14}$ \\
\hline
\end{tabular}

* 1 - значение параметра до испытаний, 2 - после испытаний.

Общеизвестно, что полифениленсульфид обладают превосходной химической стойкостью [2$5,8,9,11]:$ не растворяется практически ни в одном из известных органических растворителей и стоек к автомобильному, авиационному топливу и горюче-смазочным материалам, включая метанол, горя- чие моторные масла, смазки и антифриз, что имеет решающее значение при применении в специальной технике, авиа- и автомобилестроении.

Испытания материала марки ПФС СВ 40-1 на стойкость к агрессивным химическим средам, в частности к электролитам для жидкостных кон- 
денсаторов проводили по ГОСТ 12020 на образцах материала: температура испытаний $110^{\circ} \mathrm{C}$, продолжительность 96 часов. Как видно из данных приведенных в таблице 11, прочностные и электрофизические свойства материала остались практически на исходном уровне, кроме ударной вязкости и электрической прочности, которые снизились на $15-20 \%$.

\section{Стойкость к длительному термическому воздействию}

Длительная изотермическая выдержка образцов стеклонаполненного ПФС марок ТЕРМОРАН ПФС СВ-40 и ПФС СВ 40-1 при $150{ }^{\circ} \mathrm{C}$ в течение 2000 часов на воздухе не привела к изменению физико-механических и электрофизических характеристик, что свидетельствует об их высокой термической устойчивости.

С повышением температуры изотермического старения материала марки ТЕРМОРАН ПФС СВ40 до $220-260{ }^{\circ} \mathrm{C}$ наблюдаются изменения в уровне его свойств: имеет место повышение модуля упругости при растяжении и изгибе (жесткости), а снижение прочности при разрыве и изгибе при 220 и $240{ }^{\circ} \mathrm{C}$ не превышает $25 \%$ (таблицы $12-13$ ). Старение при температуре $260{ }^{\circ} \mathrm{C}$ приводит к дальнейшему, но не критичному (не превышающему 50 \%), изменению уровня характеристик материала (таблица 14). Отметим, что общие закономерности, характер и уровень изменения свойств стеклонаполненного полифениленсульфида марки ПФС СВ 40-1 практически идентичен материалцу марки ТЕРМОРАН ПФС СВ-40.

Примечательно, что как падение основных физико-механических характеристик, так и повышение жесткости материала стремятся к некоторому равновесному (предельному) значению, не зависящему от температуры испытаний, что свидетельствует о преимущественном протекании в материале процессов физического старения, вызванных изменением кристаллической составляющей ПФС в условиях изотермической выдержки [20]. В пользу этого косвенно свидетельствует сохранение зна-

Таблийа 11

Результаты испытаний материала марки ПФС СВ 40-1 на стойкость к электролитам

\begin{tabular}{|c|c|c|c|}
\hline \multirow{2}{*}{$\begin{array}{c}\text { Наименование параметра-критерия годности, } \\
\text { единица измерения }\end{array}$} & \multirow{2}{*}{ Метод испытаний } & \multicolumn{2}{|c|}{ Значение параметра-критерия годности } \\
\hline & & до испытаний & после испытаний \\
\hline \multicolumn{4}{|c|}{ Электролит 135 (N.N-диметилформамид) } \\
\hline Прочность при разрыве, МПа & ГОСТ 11262 & 185,0 & 180 \\
\hline $\begin{array}{l}\text { Изгибающее напряжение при максимальной } \\
\text { нагрузке, МПа }\end{array}$ & ГОСТ 4648 & 271 & 253 \\
\hline Модуль упругости при изгибе, МПа & ГОСТ 4648 & 12930 & 12860 \\
\hline Ударная вязкость по Шарпи, кДж/м² & ГОСТ 4647 & 50 & 36 \\
\hline Электрическая прочность, кВ/мм & ГОСТ 6433.3 & 32 & 27 \\
\hline $\begin{array}{l}\text { Удельное поверхностное электрическое } \\
\text { сопротивление, Ом }\end{array}$ & ГОСТ 6433.2 & $8 \cdot 10^{15}$ & $2 \cdot 10^{15}$ \\
\hline $\begin{array}{l}\text { Удельное объемное электрическое } \\
\text { сопротивление, Ом·см }\end{array}$ & ГОСТ 6433.2 & $6 \cdot 10^{16}$ & $2 \cdot 10^{14}$ \\
\hline \multicolumn{4}{|c|}{ Электролит П-4 ( $\gamma$-бутиролактон) } \\
\hline Прочность при разрыве, МПа & ГОСТ 11262 & 185,0 & 189 \\
\hline $\begin{array}{l}\text { Изгибающее напряжение при максимальной } \\
\text { нагрузке, МПа }\end{array}$ & ГОСТ 4648-2014 & 271 & 264 \\
\hline Модуль упругости при изгибе, МПа & ГОСТ 4648-2014 & 12930 & 12930 \\
\hline Ударная вязкость по Шарпи, кДж/м² & ГОСТ 4647 & 50 & 40 \\
\hline Электрическая прочность, кВ/мм & ГОСТ 6433.3 & 32 & 27 \\
\hline $\begin{array}{l}\text { Удельное поверхностное электрическое } \\
\text { сопротивление, Ом }\end{array}$ & ГОСТ 6433.2 & $8 \cdot 10^{15}$ & $6 \cdot 10^{15}$ \\
\hline $\begin{array}{l}\text { Удельное объемное электрическое } \\
\text { сопротивление, Ом·см }\end{array}$ & ГОСТ 6433.2 & $6 \cdot 10^{16}$ & $2 \cdot 10^{15}$ \\
\hline
\end{tabular}


Таблица 12

Изменение физико-механических и электрофизических свойств материала марки ТЕРМОРАН ПФС СВ-40 при температуре $220^{\circ} \mathrm{C}$

\begin{tabular}{|c|c|c|c|c|c|}
\hline \multirow{2}{*}{ Наименование параметра } & \multicolumn{5}{|c|}{ Продолжительность испытаний при 220 C, ч } \\
\hline & $\mathbf{0}$ & 48 & 120 & 288 & 720 \\
\hline Прочность при разрыве, МПа & 194 & 198 & 193 & 184 & 156 \\
\hline Модуль упругости при растяжении, МПа & 16540 & 17100 & 17050 & 17210 & 17200 \\
\hline $\begin{array}{l}\text { Изгибающее напряжение при максимальной } \\
\text { нагрузке, МПа }\end{array}$ & 292 & 290 & 286 & 265 & 239 \\
\hline Модуль упругости при изгибе, МПа & 13640 & 14230 & 14120 & 14250 & 14390 \\
\hline $\begin{array}{l}\text { Ударная вязкость по Шарпи образца } \\
\text { без надреза (в ребро), кДж/м² }\end{array}$ & 54 & 46 & 45 & 38 & 31 \\
\hline $\begin{array}{l}\text { Тангенс угла диэлектрических потерь, } \\
\text { при частоте } 1 \mathrm{MГц}\end{array}$ & 0,0025 & 0,0024 & 0,0032 & 0,0023 & 0,0028 \\
\hline Диэлектрическая проницаемость & 4,1 & 4,0 & 4,1 & 4,1 & 4,1 \\
\hline $\begin{array}{l}\text { Удельное объемное электрическое } \\
\text { сопротивление, Ом·см }\end{array}$ & $4 \cdot 10^{16}$ & $5 \cdot 10^{16}$ & $6 \cdot 10^{16}$ & $4 \cdot 10^{15}$ & $3 \cdot 10^{15}$ \\
\hline $\begin{array}{l}\text { Удельное поверхностное электрическое } \\
\text { сопротивление, Ом }\end{array}$ & $6 \cdot 10^{16}$ & $7 \cdot 10^{16}$ & $8 \cdot 10^{16}$ & $4 \cdot 10^{16}$ & $6 \cdot 10^{15}$ \\
\hline
\end{tabular}

Таблица 13

Изменение физико-механических и электрофизических свойств материала марки ТЕРМОРАН ПФС СВ-40 при температуре $240^{\circ} \mathrm{C}$

\begin{tabular}{lccccc}
\hline \multirow{1}{*}{\multicolumn{1}{c}{ Наименование параметра }} & \multicolumn{5}{c}{ Продолжительность испытаний при $\mathbf{2 4 0}{ }^{\circ} \mathbf{C , ~ ч ~}$} \\
\cline { 2 - 6 } & $\mathbf{0}$ & $\mathbf{4 8}$ & $\mathbf{1 2 0}$ & $\mathbf{2 8 8}$ & $\mathbf{7 2 0}$ \\
\hline Прочность при разрыве, МПа & 194 & 189 & 183 & 178 & 179 \\
Модуль упругости при растяжении, МПа & 16540 & 17265 & 17390 & 17380 & 17420 \\
$\begin{array}{l}\text { Изгибающее напряжение при максимальной } \\
\text { нагрузке, МПа }\end{array}$ & 292 & 281 & 268 & 254 & 228 \\
$\begin{array}{l}\text { Модуль упругости при изгибе, МПа } \\
\text { Ударная вязкость по Шарпи образца }\end{array}$ & 13640 & 13790 & 13800 & 14850 & 14670 \\
$\begin{array}{l}\text { без надреза (в ребро), кДж/м } \\
\text { Тангенс угла диэлектрических потерь, }\end{array}$ & 54 & 49 & 46 & 36 & 28 \\
$\begin{array}{l}\text { при частоте 1 МГц } \\
\text { Диэлектрическая проницаемость }\end{array}$ & 0,0025 & 0,0026 & 0,0023 & 0,0027 & 0,0030 \\
$\begin{array}{l}\text { Удельное объемное электрическое } \\
\text { сопротивление, Ом·см }\end{array}$ & 4,1 & 4,1 & 4,0 & 4,0 & 4,2 \\
$\begin{array}{l}\text { Удельное поверхностное электрическое } \\
\text { сопротивление, Ом }\end{array}$ & $4 \cdot 10^{16}$ & $2 \cdot 10^{16}$ & $5 \cdot 10^{16}$ & $6 \cdot 10^{15}$ & $4 \cdot 10^{15}$ \\
\hline
\end{tabular}

чений показателей электрофизических параметров практически на исходном уровне (таблицы 12-14).

\section{Стойкость к климатическому старению}

Одной из важнейших характеристик, определяющих возможности широкого применения по- лимерных материалов в изделиях техники является срок их службы, поскольку пластмассы подвержены старению, которым принято называть необратимое изменение их полезных свойств в результате совокупности химических и физических превращений, происходящих при переработке, хранении и эксплуатации $[33,34]$. 
Изменение физико-механических и электрофизических свойств материала марки ТЕРМОРАН ПФС СВ-40 при температуре $260{ }^{\circ} \mathrm{C}$

\begin{tabular}{|c|c|c|c|c|c|}
\hline \multirow{2}{*}{ Наименование параметра } & \multicolumn{5}{|c|}{ Продолжительность испытаний при 260 C, ч } \\
\hline & $\mathbf{0}$ & 48 & 120 & 288 & 720 \\
\hline Прочность при разрыве, МПа & 194 & 179 & 166 & 157 & 138 \\
\hline Модуль упругости при растяжении, МПа & 16540 & 17580 & 17745 & 17850 & 17755 \\
\hline $\begin{array}{l}\text { Изгибающее напряжение при максимальной } \\
\text { нагрузке, МПа }\end{array}$ & 292 & 263 & 262 & 245 & 221 \\
\hline Модуль упругости при изгибе, МПа & 13640 & 13850 & 14320 & 14640 & 14830 \\
\hline $\begin{array}{l}\text { Ударная вязкость по Шарпи образца } \\
\text { без надреза (в ребро), кДж/м² }\end{array}$ & 54 & 43 & 38 & 34 & 27 \\
\hline $\begin{array}{l}\text { Тангенс угла диэлектрических потерь, } \\
\text { при частоте } 1 \text { МГц }\end{array}$ & 0,0025 & 0,0026 & 0,0022 & 0,0027 & 0,0029 \\
\hline Диэлектрическая проницаемость & 4,1 & 4,2 & 4,1 & 4,0 & 4,0 \\
\hline $\begin{array}{l}\text { Удельное объемное электрическое } \\
\text { сопротивление, Ом·см }\end{array}$ & $4 \cdot 10^{16}$ & $3 \cdot 10^{16}$ & $6 \cdot 10^{16}$ & $6 \cdot 10^{15}$ & $4 \cdot 10^{15}$ \\
\hline $\begin{array}{l}\text { Удельное поверхностное электрическое } \\
\text { сопротивление, Ом }\end{array}$ & $6 \cdot 10^{16}$ & $2 \cdot 10^{16}$ & $3 \cdot 10^{15}$ & $1 \cdot 10^{15}$ & $3 \cdot 10^{16}$ \\
\hline
\end{tabular}

Установление срока сохраняемости свойств стеклонаполненных полифениленсульфидов в условиях хранения в неотапливаемом складском помещении при равновероятном размещении по всей территории РФ, проводили на материале марки ТЕРМОРАН ПФС СВ-40 по методике ускоренных климатических испытаний (УКИ), разработанной в соответствии с ГОСТ 9.707. Критерий сохраняемости - изменение физико-механических и электрофизических свойств материала не более, чем на $25 \%$.

Факторами климатического старения в соответствии с определяемыми выше условиями хранения и эксплуатации являются температура (как положительная, так и отрицательная), ее суточные и сезонные колебания, а также влажность воздуха. Абсолютная гидрофобность исследуемого материала [30], позволяет не учитывать фактор влажности при разработке режимов УКИ.

В соответствии с ГОСТ 9.707 минимальная положительная температура испытания должна быть равна или выше абсолютного максимума температуры хранения материала, а максимальная должна быть равна или меньше температуры, при которой начинаются фазовые, структурные или химические превращения материала. Практически значимыми фазовыми превращениями ПФС являются плавление и переход из стеклообразного в высокоэластическое состояние. Температура плавления полифениленсульфида (ПФС) составляет 280-290 ${ }^{\circ} \mathrm{C}$, а температурная область стекло- вания от 90 до $120{ }^{\circ} \mathrm{C}$. По ГОСТ 16350 предельная положительная температура воздуха на территории Российской Федерации не превышает $+45^{\circ} \mathrm{C}$, a отрицательные температуры могут достигать значения вплоть до минус $60^{\circ} \mathrm{C}$. Таким образом, для проведения УКИ максимальная положительная температура принята $90^{\circ} \mathrm{C}$, а отрицательная минус $60{ }^{\circ} \mathrm{C}$.

Исходя из данных изотермических испытаний (таблицы 12-14) и в соответствии с ГОСТ 9.707, метод 2), произведен расчет режимов УКИ: цикл испытаний, соответствующий 1 году хранения, включал выдержку при температуре $+90{ }^{\circ} \mathrm{C}$ в течение 318 ч и последующее трехкратное нагружение циклами с выдержкой при $-60^{\circ} \mathrm{C}$ в течение 3 ч и при $+60{ }^{\circ} \mathrm{C}$ в течение 2 ч.

Аналогичным образом для стеклонаполненного полифениленсульфида марки ПФС СВ 40-1 были рассчитаны режимы по сохраняемости в условиях длительного хранения в отапливаемых складских помещениях.

Как видно из результатов испытаний, представленных в таблице 15,16 , стеклонаполненные ПФС марки ТЕРМОРАН ПФС СВ-40 и ПФС СВ 40-1 характеризуется высокой климатической устойчивостью: основные прочностные характеристики материалов и показатели их электрофизических свойств практически не изменились. Снижение более чем на $10 \%$ зарегистрировано только для одного показателя - ударной вязкости 


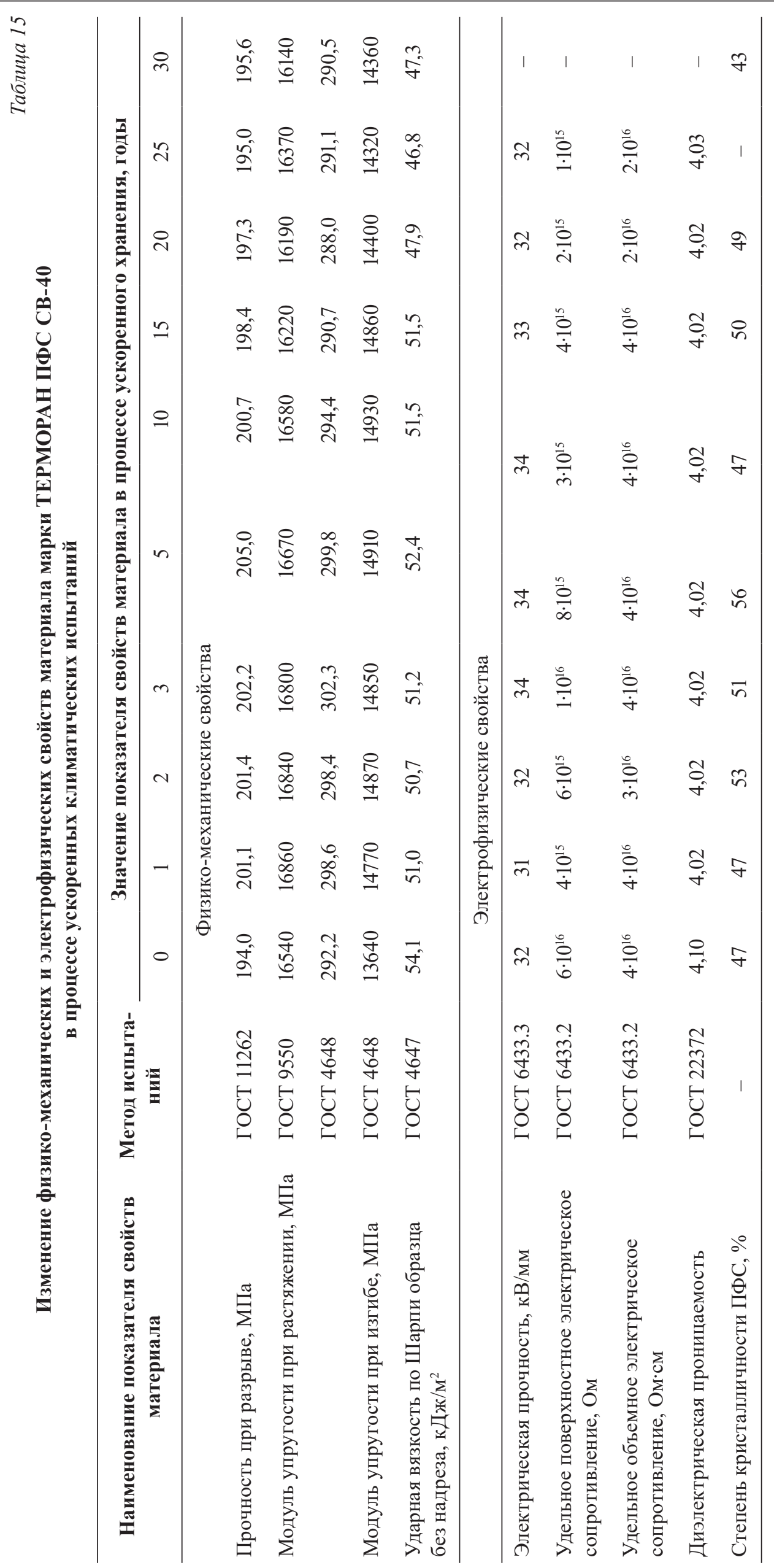


Изменение физико-механических и электрофизических свойств материала марки ПФС СВ 40-1 в процессе ускоренных климатических испытаний

\begin{tabular}{|c|c|c|c|c|c|c|c|c|c|}
\hline \multirow{2}{*}{$\begin{array}{c}\text { Наименование параметра- } \\
\text { критерия годности, единица } \\
\text { измерения }\end{array}$} & \multirow{2}{*}{$\begin{array}{c}\text { Метод } \\
\text { определения }\end{array}$} & \multicolumn{8}{|c|}{ Значение параметров-критериев годности в процессе УКИ, годь } \\
\hline & & 0 & 1 & 3 & 5 & 10 & 15 & 20 & 25 \\
\hline Прочность при разрыве, МПа & ГОСТ 11262 & 185 & 191 & 191 & 191 & 194 & 190 & 189 & 187 \\
\hline $\begin{array}{l}\text { Изгибающее напряжение } \\
\text { при максимальной нагрузке, } \\
\text { МПа }\end{array}$ & ГОСТ 4648 & 271 & 277 & 274 & 280 & 277 & 273 & 272 & 267 \\
\hline $\begin{array}{l}\text { Ударная вязкость по Шарпи, } \\
\text { кДж/м² }\end{array}$ & ГОСТ 4647 & 50 & 47 & 45 & 47 & 47 & 47 & 45 & 43 \\
\hline $\begin{array}{l}\text { Удельное поверхностное } \\
\text { электрическое } \\
\text { сопротивление, Ом }\end{array}$ & ГОСТ 6433.2 & $8 \cdot 10^{15}$ & $5 \cdot 10^{15}$ & $8 \cdot 10^{15}$ & $1 \cdot 10^{16}$ & $9 \cdot 10^{15}$ & $4 \cdot 10^{15}$ & $6 \cdot 10^{15}$ & $4 \cdot 10^{15}$ \\
\hline $\begin{array}{l}\text { Удельное объемное } \\
\text { электрическое } \\
\text { сопротивление, Ом·см }\end{array}$ & ГОСТ 6433.2 & $6 \cdot 10^{16}$ & $6 \cdot 10^{16}$ & $6 \cdot 10^{16}$ & $6 \cdot 10^{16}$ & $6 \cdot 10^{16}$ & $6 \cdot 10^{16}$ & $6 \cdot 10^{16}$ & $1 \cdot 10^{16}$ \\
\hline $\begin{array}{l}\text { Электрическая прочность, } \\
\text { кВ/мм }\end{array}$ & ГОСТ 6433.3 & 32 & 31 & 32 & 35 & 34 & 33 & 33 & 32 \\
\hline
\end{tabular}

по Шарпи, причем лишь через 20 циклов испытания (на $11,5 \%$ ). Однако эти изменения существенно меньше установленного критерия (25\%) даже при более длительных испытаниях (12,5\% через 30 циклов).

Таким образом, срок сохраняемости стеклонаполненного ПФС марки ТЕРМОРАН ПФС СВ40 в условиях хранения в неотапливаемом складском помещении при равновероятном размещении на территории РФ составляет не менее 30 лет, а материала марки ПФС СВ 40-1 - не менее 25 лет в условиях хранения в отапливаемом складском помещении при равновероятном размещении на территории РФ.

Согласно данным термогравиметрического анализа, проведенного на приборе TGA Q50 фирмы TA Instruments в соответствии с ГОСТ 9.715 (скорость подъема температуры $10{ }^{\circ} \mathrm{C} / \mathrm{Mин,} \mathrm{на} \mathrm{воз-}$ духе), изменений в характере и количественных показателях процесса деструкции образцов материала обеих марок в процессе УКИ не наблюдалось, что свидетельствует об их хорошей термостабилизации.

Согласно данным ДСК-исследований в процессе УКИ в материалах протекают процессы, приводящие к изменениям степени кристалличности, рассчитанной по энтальпии плавления ПФС (в качестве эталонного использовали значение энтальпии плавления кристаллического ПФС, равное
112 Дж/г [19]): ДСК-термограммы плавления образцов материала снимали на приборе DSC 6000 фирмы Perkin Elmer по методикам, описанным в ГОСТ 55134 (ISO 11357-1:2009) и ГОСТ Р 55135 (ISO 113572:1999). Однако, указанные структурные изменения незначительны, так как не приводят к существенным изменениям прочностных свойств.

В целом, характер изменения показателей свойств материалов в процессе УКИ (таблицы 15,16$)$, на наш взгляд, является закономерными для стеклонаполненных материалов на основе кристаллизующихся термопластов и обусловлен протеканием в материале процессов докристаллизации полимера и накоплением повреждений на границе раздела полимер-стекловолокно, приводящих к повышению дефектности (пористости) стеклонаполненного материала [35]. На начальном этапе старения превалирующим фактором снижения показателя ударной вязкости является дополнительная кристаллизация и повышение степени кристалличности ПФС. При больших временах старения (более 15 лет) при продолжающихся структурных перестройках в ПФС доминирующим становится процесс накопления повреждений на границе раздела полимер-наполнитель, вследствие сезонных и суточных перепадов температур, что и обуславливает снижение показателя ударной вязкости и некоторых других свойств материалов. 


\section{Радиачионная стойкость}

Испытания на радиационную стойкость стеклонаполненных полифениленсульфидов марок ТЕРМОРАН ПФС СВ-40 и ПФС СВ 40-1 Проводили по ГОСТ 9.706: источник излучения $-{ }^{60} \mathrm{Co}$, (средняя энергия гамма-излучения 1,25 МэВ), температура $(25 \pm 5){ }^{\circ} \mathrm{C}$, среда - воздух, мощность гамма-излучения до 5000 Гр/ч (500 крад/ч).

Контроль определяющих и характерных показателей радиационной стойкости материалов (прочность при разрыве, модуль упругости при растяжении, изгибающее напряжение при максимальной нагрузке, модуль упругости при изгибе и ударная вязкость) показал, что снижение их параметров при достижении значения поглощенной дозы излучения 10 Мрад не превысило $8 \%$, а при поглощенной дозе 100 Мрад - составило менее, чем на $12 \%$ от исходного уровня, т.е. материалы марок ТЕРМОРАН ПФС СВ-40 и ПФС СВ 40-1 является радиационностойким по ГОСТ 25645.331.

Приведенные результаты исследований вместе с ранее опубликованными данными [18-22, 3032] дают достаточно полное представление о прочностных, технологических и эксплуатационных характеристиках материалов марки ТЕРМОРАН и их стойкости к термическим, климатическим и др. воздействующим факторам, что позволяет принять обоснованное решение о возможности их применения в конкретных изделиях с заданными условиями эксплуатации.

Высокий уровень прочностных, электрои теплофизических характеристик стеклонаполненных отечественных полифениленсульфидов марок ТЕРМОРАН и ПФС СВ 40-1 позволяют рекомендовать их для изготовления различных деталей изделий аэрокосмической и специальной техники, нефте- и газодобычи, автомобилестроения, электротехнической и др. отраслей промышленности, эксплуатируемых в жестких условиях и широком диапазоне температур.

\section{Лuтература}

1. Дариенко И.Н. Экспертный союз. 2012. №3.

2. Новые полимеры: полифениленсульфид // Евразийский химический рынок. 2008. №3(39). С. 14-21.

3. Йохэннинг Ф. Полимерные материалы. 2012. №2. C. 40-44.

4. Михайлин Ю.А. Термоустойчивые полимеры и полимерные материалы. СПб.: Профессия. 2006. 624 с.

5. Михайлин Ю.А. Специальные полимерные композиционные материалы. СПб.: Научные основы и технологии. 2009. 660 c.

6. Рынок полифениленсульфида продолжает расти // The Chemical Journal. 2005. Октябрь-ноябрь. С. 73-74.
7. Тенденции рынка полифениленсульфида в мире и России // Евразийский химический рынок. 2013. №10(109). C. 24-30.

8. Жукова И. Суперконструкционный полимер полифениленсульфид, сравнение областей его применения в России и мире // Презентация доклада. Интерпластика. 2017. Москва, 24-27 января 2017 / сайт: plastinfo.ru.

9. ФОРТРОН ${ }^{\circledR}$ Полифениленсульфид (ПФС) / Проспект фирмы Тикона. $-2015 .-55$ с.

10. Properties of DIC PPS / Проспект фирмы DIC/ Сайт: http://www.dic-global.com/eu/en/products/pps/pdf/ dic_pps_property.pdf

11. Бикша Дженни. Вестник электроники. 2014. №1(47). C. 24-27.

12. А.С. СССР 525717, МКП C08G75/16. Способ получения полиариленсульфидов / Кемеровский научноисследовательский институт химической промышленности - №2080293/05; заявл. 04.12.1974; опубл. 25.08.1976.

13. А.С. СССР 627141, МКП С08G75/16. Способ получения полиариленсульфидов / Институт элементоорганических соединений им. А.Н Несмеянова. №2471801/23-05; заявл. 04.04.1977; опубл. 05.10.1978.

14. А.С. СССР 730721, МКП C08G75/16. Способ получения полиариленсульфидов / Ордена Ленина институт элементоорганических соединений $\mathrm{AH}$ СССР. - №2573276/23-05; заявл. 27.01.1978; опубл. 30.04.1980.

15. А.С. СССР 1429547, МКП C08G75/16. Способ получения полиариленсульфида / Институт элементоорганических соединений им. А.Н. Несмеянова и Кемеровский научно-исследовательский институт химической промышленности - Кемеровское НПО «Карболит». - №4148003/23-05; заявл. 23.03.1986; опубл. 15.09.1990.

16. Неделькин В.И., Зачернюк Б.А., Андрианова О.Б. Российский химический журнал. 2005. T. XLIX. №6. С. 3-10.

17. Петрова Г.Н., Бейдер Э.Я. Российский химический журнал. 2010. Т. 54. №1. С. 34-40.

18. Екимов А.И., Калугина Е.В., Саморядов А.В., Битт B.B. Приказщиков А.В. Исследование композиционных материалов на основе полифениленсульфида // «Технологии и материалы для экстремальных условий». Материалы 11-ой Всероссийской конференции. г. Москва, 8-13 ноября 2016 г.». М.: МЦАИ PAH. 2016. C. 4-9.

19. Битт В.В., Кудрявиева М.В., Иванов А.Н., Саморядов А.В., Приказщиков А.В. Калугина Е.В. Полимерные трубы. 2017. № 1 (55). Апрель. С. 52-59.

20. Битт В.В., Борисова О.В., Кудрявцева М.В., Калугина Е.В., Саморядов А.В. Исследование термических характеристик полифениленсульфидов // «Технологии и материалы для экстремальных условий». Материалы Всероссийской научной конференции. г. Звенигород, 10-14 декабря 2018 г.». - М.: МЦАИ PAH. 2018. C. 227-235.

21. Саморядов А.В., Усенко Е.С. Высокотермостойкие композиционные материалы ТЕРМОРАН 
для изделий аэрокосмической техники // «Материалы и технологии нового поколения для перспективных изделий авиационной и космической техники» IV Всероссийской научно-технической конференции. г. Москва, 26 августа 2019 г.» - М.: ФГУП «ВИАМ» ГНЦ РФ. 2019. С. 164-177.

22. Ivanov V.B., Bitt V.V., Solina E.V., Samoryadov A.V. Polymers. 2019. V. 11. №10. P. 1579-1584. (DOI:10.3390/polym11101579).

23. Лишевич И.В., Бахарева В.Е., Саргсян А.С., Скобелева Е.Л. Вопросы материаловедения. 2009. №1(57). C. $111-115$.

24. Лишевич И.В. Создание антифрикционных теплостойких углепластиков для высокоскоростных подшипников насосов и паровых турбин. Дис. канд. техн. наук. С-Пб.: ФГУП «ЦНИИ КМ «Прометей». 2015. $154 \mathrm{c}$.

25. Феофанов Б.Н. Новые литьевые термопластичные компаунды конструкционного назначения на основе полифениленсульфида (ПФС) // Презентация доклада. Армия-2019.-Москва, 18-20 августа 2019. https:// plastinfo.ru/information/news/42512_02.07.2019/.

26. Polyfenylenesulfide Resins. Проспект. - Phillips Petroleum Corp., 1992. 24 c.
27. Properties of DIC PPS / Проспект фирмы DIC/ Сайт: https://www.dic-global.com/pdf/products/catalog/dic pps_property.pdf

28. Барвинский И.А., Барвинская И.Е. Справочник по литьевым термопластичным материалам / Сайт: www.barvinsky.ru.

29. База полимеров / Сайт: www.plasinfo.ru.

30. Саморядов А.В., Калугина Е.В., Битт В.В. Пластические массы. 2019. №7-8. С. 52-56.

31. Иванов В.Б., Солина Е.В., Саморядов А.В. Влияние условий облучения на фотодеструкцию ударопрочного композита на основе полифениленсульфида // Все материалы. Энциклопедический справочник. 2019. № 11 C. 32-37. DOI: 10.31044 / 1994-6260-2019-0-11-32-37.

32. Ivanov V.B., Solina E.V., Samoryadov A.V. Polymer Science, Series D. 2020. V. 13. N 3. P. 353-357. (DOI: 10.1134/1995421220030089).

33. Эмануэль Н.М., Бучаченко А.Л. Химическая физика старения и стабилизации полимеров. - М.: Наука, 1982.359 c.

34. Карпухин О.Н. Успехи химии. 1980. Т. 49. Вып. 8. C. $1523-1553$.

35. Саморядов А.В., Паршиков Ю.Г. Российский химический журнал. 2016. Т. 60. №4. С. 64-79. 